\title{
Phosphogypsum waste as additives to lime stabilization of bentonite
}

\author{
Safae Oumnih ${ }^{1,2}$, Nadia Bekkouch ${ }^{1,3}$, El Khadir Gharibi ${ }^{2}$, Nathalie Fagel ${ }^{1}$, Kamal Elhamouti ${ }^{3}$ \\ and Meriam El Ouahabi ${ }^{1^{*}}$ (D)
}

\begin{abstract}
Waste recycling with increasing the lifecycle of resource is a novel approach for enhancing circular economy. Within this context, this study aims to give a second life cycle to phosphogypsum (PG) waste, which is a byproduct from phosphoric acid manufacture, as useful resources. This study evaluates the sustainability of this harmful waste, which is accumulated in large stockpiles and becomes hazardous during storage, and to stabilize bentonite-based concrete intended for road construction.

The effect of raw bentonite (Ca-Na montmorillonite), PG, and lime on the properties of cementitious materials has been investigated through various tests. The properties examined include chemistry (X-ray Fluorescence Spectrometry), mineralogy (X-ray Powder Diffraction and Fourier-Transform Infrared Spectroscopy), calorimetry (Differential Thermal Analysis/Thermogravimetry) and microstructure (Scanning Electron Microscopy) of the mortar based on different mixtures of bentonite, PG and lime. The result show that lime and PG addition involves in the formation of new nanocrystalline phases and the disappearance of certain minerals as portlandite. Calcium silicate hydrate gel appeared in the mixture with $8 \%$ of lime, whereas strätlingite was neoformed in the mixture with $8 \%$ of lime and $8 \%$ of PG. These nanocrystalline phases are responsible for enhancing mechanical strength through the pozzoloanic reaction.
\end{abstract}

Keywords: Phosphogypsum, Bentonite, Microstructure, CSH gel, Strätlingite

\section{Introduction}

Phosphogypsum (PG), produced from phosphoric acid production, consists mainly of $\mathrm{CaSO}_{4} \cdot 2 \mathrm{H}_{2} \mathrm{O}$ and some impurities such as $\mathrm{P}_{2} \mathrm{O}_{5}, \mathrm{~F}^{-}$, and organic substances. Many phosphate fertilizer-producing countries face problems of PG waste with the high waste yield (5 kg PG generated $1 \mathrm{~kg}$ of phosphoric acid produced) [1].

The annual world production of PG has been estimated to be around 200-300 Mt [2]. Most of this byproduct $(85 \%)$ is stored in large stockpiles without any treatment. About $15 \%$ of this waste is re-used in building materials, soil amendment for soil remediation, agricultural fertilizers and Portland cement manufacture (e.g., [3-7]).

In Morocco the annual production of PG is estimated at $20 \mathrm{Mt}$. It is accumulated in large stockpiles which occupy vast land areas and then discharged into the sea

\footnotetext{
* Correspondence: meriam.elouahabi@uliege.be

${ }^{1}$ Department of Geology, University of Liege, B-4000 Liege, Belgium

Full list of author information is available at the end of the article
}

when pile is full [8]. The discharge causes environmental damage when they interact with aquatic environments $[9,10]$.

Over the last years, attempts were made to use PG in a wide range of applications such as road and rail works fills and building constructions, in particular in concrete and supersulfated cement, and high alumina cement [11-14].

Lime is natural pozzolans, widely used to improve durability of the concrete against chemical attack, mainly due to reduced permeability $[15,16]$. Raw lime $(\mathrm{CaO})$ is formed from the process of decarbonation of calcareous rocks by heating. It is available at low cost and generates a low ecological footprint. Raw bentonite can be improved by adding low percentages of lime, involving in short-term and long-term reactions [17]. Short-term reactions include ion exchange, flocculation and carbonation. The long-term pozzolanic reactions enhance the resistance and compressibility of clays [18].

(c) The Author(s). 2019 Open Access This article is distributed under the terms of the Creative Commons Attribution 4.0 International License (http://creativecommons.org/licenses/by/4.0/), which permits unrestricted use, distribution, and 
Bentonite mixed with lime is used in different fields as in biochemistry for remediation of oil contaminated soil [19] as additives to stabilize organic and inorganic pollutants [20], and to decrease swelling behavior of clay and enhance its mechanical resistance [21]. Calcium sulfate (e.g. gypsum) was successfully tested as a stabilizing agent for expansive clay soils $[22,23]$.

PG further improves binder action and promotes a rapid reaction between lime and fly ash for road base materials $[24,25]$. However, suitability of PG and lime aggregates to stabilize bentonite has been poorly studied. In addition, the majority of previous studies use chemically modified clay and heated lime and clay to stabilize soil.

This study falls within the framework of sustainable management of resources by recycling waste and limiting energy consumption during calcination process. For this purpose, bentonite, lime and PG are tested for binder action, in their raw state without any calcination and chemical modification. In addition, chemical study of microstructure of different mixtures with the addition of lime and PG on stabilization of clay is lacking. Thus, the present study aims for a better understanding of chemistry and microstructure changes occurring in different amounts of lime and PG.

\section{Materials and methods}

\section{Raw materials}

The bentonite used in this study is belonging to the Trebia deposit, situated at about $18 \mathrm{~km}$ west of the Nador city (Northeast Morocco). The Trebia deposit has mineable reserves of $\sim \mathbf{1 . 2 5} \mathbf{M t}$. Genesis of this bentonite is linked to hydrothermal activity of the Gourougou volcano over the Neogene. This deposit is associated with rhyolitic-pyroclastics lava and pearlites [26]. Bentonite from this area comprises of dioctahedral smectite, with high swelling behavior, high compressibility and poor strength when hydrated [27].

The hydrated lime, $\mathrm{Ca}(\mathrm{OH})_{2}$, used in this study is an industrial material destined to the local Moroccan market (Oujda, Northeast Morocco). The PG $\left(\mathrm{CaSO}_{4} \cdot 2 \mathrm{H}_{2} \mathrm{O}\right)$ is a phosphate industry waste from the Cherifien office of Phosphate of Jorf Lasfaar (El jadida, Morocco).

\section{Aggregates preparation}

Bentonite, lime and PG are used in their raw state without any calcination and chemical modification. The samples are labeled referring to the content of lime, PG and bentonite. Different mixtures of bentonite-lime and bentonite-lime-PG were prepared by mixing variable percentages of lime (from 5, 8, 10 to 15\%) and PG (from $2,4,8$ to $10 \%$ ) by dry weight of bentonite. Water was added to the mixture of dry materials until the mass attained uniform consistency. Afterward, the mix was placed inside of a cylindrical mold with a diameter of $1.3 \mathrm{~cm}$ and a height of $2.3 \mathrm{~cm}$. The specimen was extracted and placed in airtight polythene bags, which were placed inside a desiccator for curing for 3, 7, 14 and 28 d. The specimen was taken out of the desiccator and polythene bag after the desired period of curing and tested for unconfined compressive strength, Differential Thermal Analysis/Thermogravimetry (DTA/TG), X-Ray Diffraction (XRD) and Scanning Electron Microscopy (SEM).

\section{Experimental procedures}

Raw bentonite, lime, PG and different mixtures were characterized using XRD, X-Ray fluorescence (XRF), DTA/TG and Fourier-Transform Infrared Spectroscopy (FTIR) techniques.

The mineralogical composition was identified on powdered samples $(<250 \mu \mathrm{m}$ size fraction) by XRD using a powder Brucker D8-Advance diffractometer, with copper anticathode (University of Liege, Belgium). The angular range between $5^{\circ}$ and $60^{\circ} 2 \theta$. The X-ray patterns were analyzed by the DIFFRACplus EVA software (Brucker) and mineralogical phases were determined semi-quantitatively ( $\pm 5 \%)$.

For bentonite, additional measurements were performed on oriented aggregates prepared from the $<2 \mu \mathrm{m}$ fraction obtained by suspension of bulk sample in distilled water. The $<2 \mu \mathrm{m}$ fraction was retrieved from the suspension according to Stoke's law, placed on a glass slide and the XRD patterns recorded between $2^{\circ}$ and $30^{\circ}$ $2 \theta$ using the same step size and time per step parameters. To identify the clay phases on the $<2 \mu \mathrm{m}$ fraction, the oriented aggregates were subjected to three successive treatments, i.e., air drying, ethylene glycol saturation and heating to $500{ }^{\circ} \mathrm{C}$ for $4 \mathrm{~h}$.

XRF spectroscopy using a PanalyticalAxios spectrometer equipped with Rh-tube (University of Liege, Belgium) was used to determine chemical composition of major elements.

DTA/TG analysis was carried out using a TGA-2000 Analyzer under atmospheric conditions (University of Liege, Department of Geology, Belgium). The samples were heated from room temperature to $1000^{\circ} \mathrm{C}$ with a rate of $5^{\circ} \mathrm{C} \mathrm{min}^{-1}$.

The NICOLET NEXUS Fourier Transform Spectrophotometer from the University of Mohammed Premier (Oujda, Morocco) was used to determine the groups of vibrations in the raw material. The wavelengths range from 400 to $4000 \mathrm{~cm}^{-1}$ with the spectral resolution at 4 $\mathrm{cm}^{-1}$. Samples were prepared by mixing $1 \%$ of the compound with $\mathrm{KBr}$.

The compressive strength was determined according to the uniaxial resistance test using a worm gear motor controlled by a Microstep Drive (Parker) and a 
compumotor PC23 adaptor (University of Liege, ArGEnCo Laboratory, Belgium). A constant speed charge of $144 \mathrm{kN} \mathrm{min}^{-1}$ is applied until the block is broken.

SEM images were performed on raw bentonite and different mixtures using a Philips microscope model XL30 (University of Liege, Belgium). In situ chemical composition was determined by energy-dispersive $\mathrm{X}$-ray spectroscopy. The images were obtained with a secondary electron detector at a voltage of $10 \mathrm{kV}$ on goldsputtered powdered samples.

\section{Results}

\section{Characterization of raw materials}

The XRD spectrum of bentonite shows a dominance of smectite with characteristics diffraction peaks at 6.2, 19.9, 27.7 and $34.62 \theta$ (Fig. 1). K-feldspar and plagioclase with small amount of quartz form this raw bentonite. Regarding the clay $<2 \mu \mathrm{m}$ fraction, the results indicate a diffraction peak at 7.2 $2 \theta$ under air dried, showing an expansion of the 001 reflection to around $5.22 \theta$ upon ethylene glycol saturation run, and collapses to $9.02 \theta$ after heating at $500{ }^{\circ} \mathrm{C}$. The d001-value of smectite peak is sharp and symmetric suggesting its neoformed origin (Fig. 2). Chemical composition of bentonite is made by $\mathrm{SiO}_{2}$ (51.0\%) and $\mathrm{Al}_{2} \mathrm{O}_{3}$ (24.4\%), with small quantity of $\mathrm{Fe}_{2} \mathrm{O}_{3}(2.8 \%), \mathrm{CaO}(1.1 \%)$ and $\mathrm{MgO}$ (1.1\%). XRF data (Table 1) allowed to calculate theoretical formula of smectite, which is an montmorillonite $(\mathrm{Na}, \mathrm{Ca})_{0.33}(\mathrm{Al}$, $\mathrm{Mg})_{2} \mathrm{Si}_{4} \mathrm{O}_{10}(\mathrm{OH})_{2}\left(\mathrm{H}_{2} \mathrm{O}\right)_{3}$.

PG sample contains calcium sulfate dihydrate $\mathrm{CaSO}_{4} \cdot 2 \mathrm{H}_{2} \mathrm{O}$, calcite and quartz (Fig. 1). Chemically, PG is mainly composed of $\mathrm{SO}_{3}(46.9 \%), \mathrm{CaO}$ (31.5\%), $\mathrm{MgO}$ (1.6\%) and $\mathrm{P}_{2} \mathrm{O}_{5}$ (0.4\%). PG also contains some impurities of environmental concern such as residual acids, fluorides, sulphate ions, trace metals (e.g., $\mathrm{Cr}, \mathrm{Cu}, \mathrm{Zn}$, $\mathrm{Cd}, \mathrm{Ba}, \mathrm{Cu}, \mathrm{Ni}, \mathrm{Sr}, \mathrm{U}$, etc.), and organic matter as aliphatic compounds of carbonic acids, amines and ketones $[28,29]$. Lime sample is mainly composed of $\mathrm{CaO}$ (69.5\%), $\mathrm{MgO}$ (4.3\%), $\mathrm{Al}_{2} \mathrm{O}_{3}(1.2 \%)$ and $\mathrm{SiO}_{2}$ (1.0\%).

The DTA/TG results (Table 2) show an endothermic peak at $135{ }^{\circ} \mathrm{C}$ for bentonite, associated with a loss of mass of $10 \%$, mainly due to desorption of physisorbed water molecules. Two other endothermic peaks are observed at 520 and $680{ }^{\circ} \mathrm{C}$, accompanied by a loss of mass of 3.6 and $1.2 \%$, respectively, mainly related to dehydroxylation of montmorillonite. For PG, a loss of mass of $20 \%$ is observed between 125 and $450{ }^{\circ} \mathrm{C}$ accompanied by an endothermic peak at $180^{\circ} \mathrm{C}$ due to PG dehydration $\left(\mathrm{CaSO}_{4} \cdot+2 \mathrm{H}_{2} \mathrm{O} \rightarrow \mathrm{CaSO}_{4}\right)$. In addition, two other endothermic peaks are observed at 475 and $780{ }^{\circ} \mathrm{C}$. They are accompanied by a loss of mass of $23 \%$ due to the decomposition of portlandite on free lime $\left(\mathrm{Ca}(\mathrm{OH})_{2} \rightarrow\right.$
$\left.\mathrm{CaO}+\mathrm{H}_{2} \mathrm{O}\right)$. According to the TG data, the degree of hydration of bentonite is $n=3$.

The FTIR spectra of the raw materials are shown in Fig. 3. This spectrum exhibits several bands and the assignment of the FTIR absorption bands is shown in Table 3. The SEM images of raw bentonite are reported in Fig. 4, show typical form of authigenic montmorillonite as honeycomb structures.

\section{Characterization of the mixtures}

The XRD diffraction patterns of the Bentonite $+8 \%$ Lime and Bentonite $+8 \%$ Lime $+8 \%$ PG samples show the appearance of calcium silicate hydrate $(\mathrm{CSH})$ gel $\left(\mathrm{CaO}, \mathrm{SiO}_{2}, \mathrm{H}_{2} \mathrm{O}\right)$ at $\mathrm{d}=3.0 \AA$ (29.4 20, Fig. 1). This nano-crystalline compound has a short distance structuring $(<100 \AA)$; this is equated with gel occurrence. Furthermore, strätlingite is neoformed only in the Bentonite $+8 \%$ Lime $+8 \%$ PG sample at $d=4.2 \AA(22.02 \theta$, Fig. 1).

In raw bentonite, the diffraction reflection of montmorillonite is at $d=13.0 \AA$ (9.8 20) has changed its shape in the Bentonite $+8 \%$ Lime and Bentonite $+8 \%$ Lime + $8 \%$ PG mixtures. It is larger with an extension towards $12 \AA(7.42 \theta)$ and $14 \AA(6.32 \theta)$, suggesting a transformation of montmorillonite into illite-smectite mixed layers (Fig. 1). This transformation is associated with the appearance of silicates aluminum and calcium (strätlingite, $\mathrm{CSH})$ at $\mathrm{d}=12.5 \AA$ (7.1 20). In the Bentonite $+8 \%$ Lime mixture, a significant increase in the intensity of feldspar (anorthite) reflection at $\mathrm{d}=3.2 \AA(27.82 \theta)$ is observed by comparison to the raw bentonite. However, in the Bentonite $+8 \%$ Lime $+8 \%$ PG mixture, a decrease in the peak intensity of plagioclase can be observed compared to the raw bentonite. It reflects the hydrolyzing conditions, as underlined by the change in $\mathrm{pH}$ of the mixture (Table 4).

Compressive strength of the mixtures is shown in Fig. 5. At the early age (3 d) all the mixtures yielded higher compressive strengths $(\mathrm{Max}=0.032 \mathrm{MPa})$ than the raw bentonite. After $14 \mathrm{~d}$, the compressive strengths of the mixtures increase with the curing age. The higher compressive strength is noticed for the Bentonite $+8 \%$ Lime $+8 \%$ PG mixture up to $28 \mathrm{~d}(\sim 0.10 \mathrm{MPa})$. The lime combined with PG enhances pozzolanic properties and particle packing density, improving concrete strength and density.

On SEM images the montmorillonite crystals present a different shape with the addition of $8 \%$ of lime in comparison to the raw bentonite (Fig. 4d-f). SEM images confirm the appearance of $\mathrm{CSH}$ gel (Fig. 4h and $\mathrm{g}$ ). These nano-particles influence the crystallographic structure of bentonite. The montmorillonite crystals are still visible as the former ones, but capped by the $\mathrm{CSH}$ gel. A further alteration of montmorillonite crystal is 


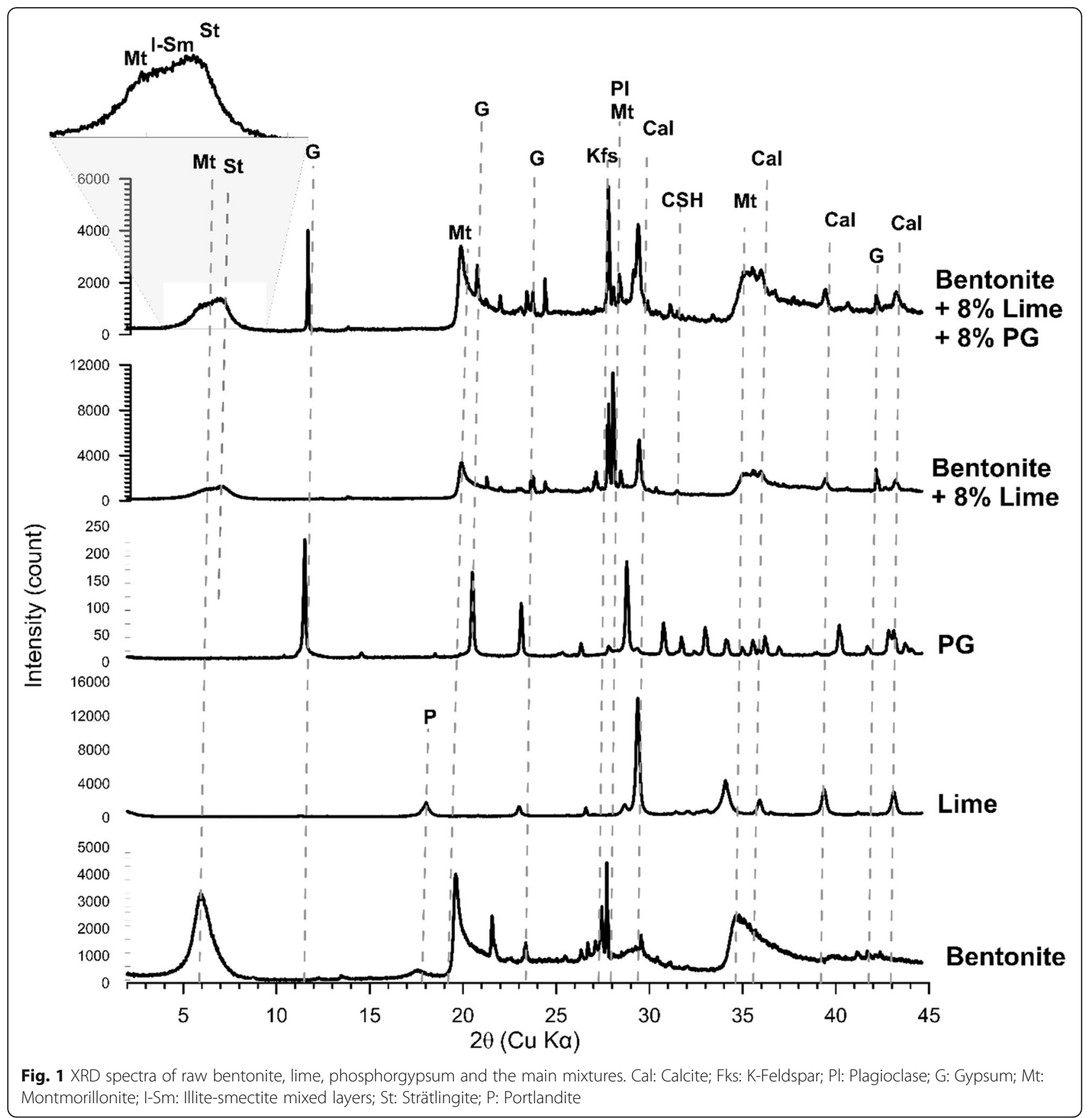

evidenced for the Bentonite $+8 \%$ Lime $+8 \%$ PG mixture, associated with nano-silica gel development.

\section{Discussion}

Compressive strength and microstructural characteristics

Natural pozzolans are tremendous source of reactive silica and alumina required for geopolymer synthesis as an alternative binder for Portland cement. Factors affecting the degree of geopolymerization are particle size, type and concentration of alkali activators and curing conditions [30,31]. In particular, $\mathrm{Al}_{2} \mathrm{O}_{3}$ supplied by bentonite improves mechanical properties of the material by increasing the geopolymeric phases (gels and sträntlingite) which imprisons the initially crystalline phases of the starting material, and reduce the efflorescence [32].

The appearance of sträntlingite and calcium gels in the mixtures attests for the increasing of mechanical resistance through pozzolanic reactions or geopolymerization. Those reactions imply the formation of new crystalline phases and the disappearance of some minerals initially present in the raw material. The decrease of reflection intensities of K-feldspar and the disappearance of calcite 


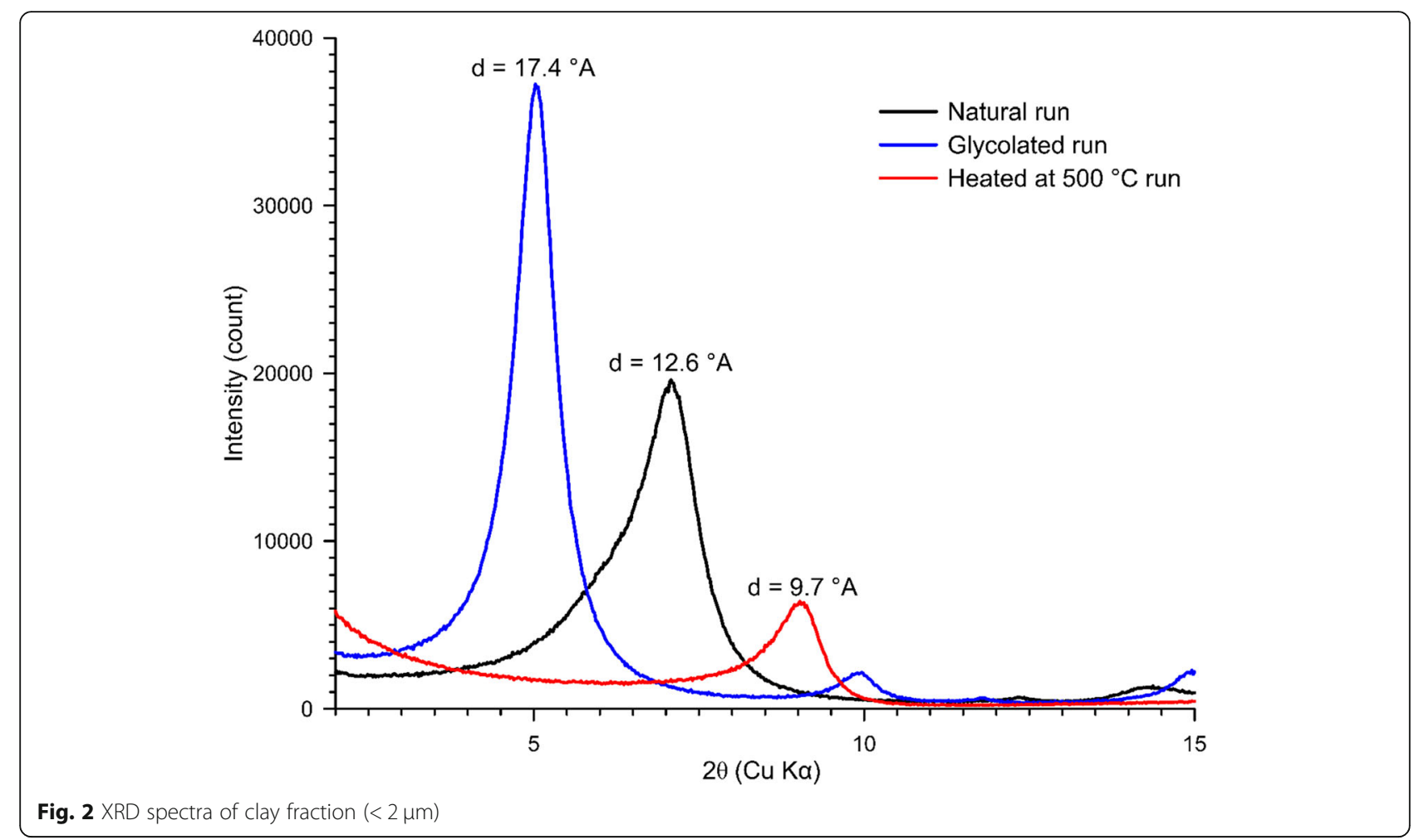

(Fig. 1) are among the main observed changes. The formation of new crystalline phases (generally hydrated minerals and gel) occurs in alkaline conditions with low $\mathrm{Na}$ and $\mathrm{Ca}$ amount $(\mathrm{Ca} / \mathrm{Si}$ and $\mathrm{Na} / \mathrm{Si}<0.1$, Table 4). $\mathrm{CSH}$ phases are formed, due to the presence of $\mathrm{CaO}$ as natural pozzolan in the mixture and the small amount of $\mathrm{Na}_{2} \mathrm{O}(<2 \%)$.

The addition of $8 \%$ of hydrated $\mathrm{Ca}(\mathrm{OH})_{2}$ lime to the Na-rich montmorillonite induces the adsorption of $\mathrm{Ca}^{2+}$ and the responsiveness of $\mathrm{OH}^{-}$ions, thus increasing the negative charge of the surface. The addition of more lime resulted in the appearance of flocs, so the $\mathrm{OH}^{-}$ions

Table 1 Major chemical composition of raw bentonite and PG in wt\%. L.O.I: Loss On Ignition. LOD: Limit of detection

\begin{tabular}{lll}
\hline Major oxides & $P G(\%)$ & Raw bentonite (\%) \\
\hline $\mathrm{SiO}_{2}$ & 0.50 & 51.01 \\
$\mathrm{Al}_{2} \mathrm{O}_{3}$ & 0.11 & 24.36 \\
$\mathrm{Fe}_{2} \mathrm{O}_{3}$ & 0.08 & 2.78 \\
$\mathrm{CaO}$ & 31.51 & 1.13 \\
$\mathrm{MgO}$ & 1.59 & 1.14 \\
$\mathrm{SO}_{3}$ & 46.9 & 0.80 \\
$\mathrm{~K}_{2} \mathrm{O}$ & 0.03 & 0.66 \\
$\mathrm{TiO}_{2}$ & $<\mathrm{LOD}$ & 0.17 \\
$\mathrm{Na}_{2} \mathrm{O}$ & 0.03 & 1.58 \\
$\mathrm{P}_{2} \mathrm{O}_{5}$ & 0.35 & 0.05 \\
$\mathrm{L.O} . \mathrm{I}$ at $1000{ }^{\circ} \mathrm{C}$ & 16 & 20 \\
\hline
\end{tabular}

dissociate these weakly acidic flocs to provide additional negative sites for binding the clay particles to the $\mathrm{Ca}^{2}+$ ions.

Pozzolanic reaction starts with an attack on the $\mathrm{SiO}_{2}$ or $\mathrm{Al}_{2} \mathrm{O}_{3}-\mathrm{SiO}_{2}$ by $\mathrm{OH}^{-}$ions, and breaks of bonds between the silicon and oxygen atoms [33]. When lime is added, the $\mathrm{pH}$ increases to $\sim 10.5$, leading to hydrolyzing of the feldspar that affects the crystalinity of montmorillonite (Table 4, Fig. 4a-c). The hydroxide ions $\mathrm{OH}^{-}$released from the lime hydration reaction combine with aluminum disassociated from montmorillonite $\mathrm{Al}_{2} \mathrm{Si}_{4} \mathrm{O}_{10}(\mathrm{OH})_{2} \cdot \mathrm{nH}_{2} \mathrm{O}$ to form $2 \mathrm{Al}(\mathrm{OH})_{4}{ }^{-}$[34], according to the following equation:

$$
\begin{aligned}
& \mathrm{Al}_{2} \mathrm{Si}_{4} \mathrm{O}_{10}(\mathrm{OH})_{2} \cdot \mathrm{nH}_{2} \mathrm{O}+2(\mathrm{OH})^{-}+ \\
& 10 \mathrm{H}_{2} \mathrm{O} \rightarrow 2 \mathrm{Al}(\mathrm{OH})_{4}{ }^{-}+4 \mathrm{H}_{4} \mathrm{SiO}_{4}+\mathrm{nH}_{2} \mathrm{O}
\end{aligned}
$$

The alumina and silica can then combine with $\mathrm{Ca}^{2+}$ and $\mathrm{OH}^{-}$, at $\mathrm{pH}=12.4$, to form $\mathrm{CSH}$ and calcium aluminate hydrate $(\mathrm{CAH})$ gels [35].

When PG is added, strätlingite occurs in alkaline conditions through secondary reaction; $\mathrm{CSH}+\mathrm{CH}+\mathrm{AH}_{3}+$ $3 \mathrm{H} \rightarrow \mathrm{C}_{2} \mathrm{ASH}_{8}$ [36]. Its occurrence is compatible with the presence of gypsum and calcite and it binds insignificant sulfate and carbonate [35].

Thermogravimetric analyses do not show any significant mass loss during geopolymerization in the mixtures (Table 2). Pozzolanic reaction may be associated with a low mass loss [31]. 
Table 2 DTA endothermic peaks recorded in the raw material and the mixtures and their interpretations

\begin{tabular}{|c|c|c|c|}
\hline Samples & Endothermic peaks $\left({ }^{\circ} \mathrm{C}\right)$ & Mass loss (\%) & Interpretations \\
\hline \multirow[t]{2}{*}{ Bentonite } & 135 & 10 & Desorption of physisorbed water molecules. \\
\hline & 520,680 & $3.61,1.17$ & $\begin{array}{l}\text { Dehydroxylation of montmorillonite and the quartz } \\
\text { transformation from a to } \beta \text {. }\end{array}$ \\
\hline \multirow[t]{2}{*}{ Lime } & 500 & 13 & Decomposition of portlandite on hydrated lime $\left(\mathrm{Ca}(\mathrm{OH})_{2}\right)$. \\
\hline & 780 & 10 & Calcite dycarboxylation. \\
\hline \multirow[t]{2}{*}{$P G$} & 180 & 20 & Gypsum dehydration $\left(\mathrm{CaSO}_{4} \cdot 2 \mathrm{H}_{2} \mathrm{O} \rightarrow \gamma-\mathrm{CaSO}_{4}\right)$. \\
\hline & 475,780 & 23 & Portlandite decomposition $\left(\mathrm{Ca}(\mathrm{OH})_{2} \rightarrow \mathrm{CaO}+\mathrm{H}_{2} \mathrm{O}\right)$. \\
\hline \multirow[t]{2}{*}{ Bentonite + 8\% Lime } & 135 & 10 & Desorption of physisorbed water molecules. \\
\hline & 500,675 & 10 & $\begin{array}{l}\text { Dehydroxylation of montmorillonite and the quartz } \\
\text { transformation from a to } \beta \text {. }\end{array}$ \\
\hline \multirow[t]{2}{*}{ Bentonite $+8 \%$ Lime $+8 \%$ PG } & 150 & 10 & Desorption of physisorbed water molecules. \\
\hline & 515,665 & 9 & $\begin{array}{l}\text { Dehydroxylation of montmorillonite and the quartz } \\
\text { transformation from a to } \beta \text {. }\end{array}$ \\
\hline
\end{tabular}

\section{Influence of $\mathrm{pH}$}

\section{Bentonite-lime mixture $(\mathrm{pH}=9.6)$}

The weakly basic character of montmorillonite $(\mathrm{pH}=$ 8.5) can be explained by the fact that montmorillonite consists of two siliceous basal surfaces that tend to release hydroxyl ions into the solution. The slight increase in $\mathrm{pH}$ of the bentonite-lime mixture $(\mathrm{pH}=9.6)$ favors cementation due to pozzolanic reactions (Table 4). This reaction needs time and a highly alkaline environment ( $\mathrm{pH}=12.4$ ) [37]. The formation of silicate and aluminum hydrates is caused by the substitution of the cations in montmorillonite by $\mathrm{Ca}^{2+}$ ions [38]. The strength of limetreated bentonite primarily depends on the dissolved $\mathrm{SiO}_{2}$ and $\mathrm{Al}_{2} \mathrm{O}_{3}$ available for pozzolanic reactions, as

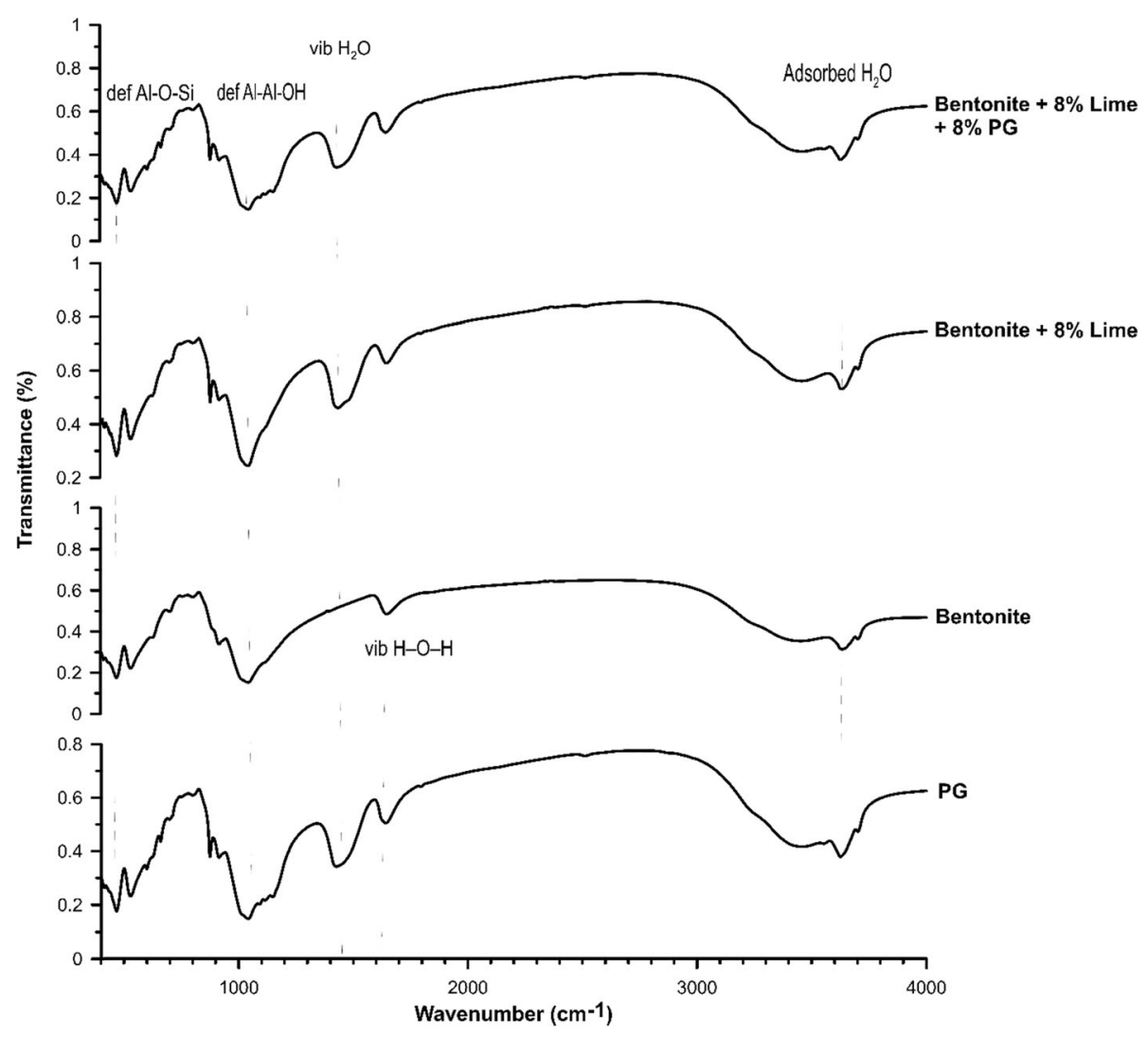

Fig. 3 FTIR spectra of the raw materials and the mixtures 
Table 3 Assignment of FTIR absorption bands

\begin{tabular}{|c|c|c|}
\hline Bands, $\mathrm{cm}^{-1}$ & Samples & Significance \\
\hline $464.4 ; 524.2$ & $\begin{array}{l}\text { Bentonite } \\
B+8 \% L \\
B+8 \% L+8 \% P G\end{array}$ & $\begin{array}{l}\text { Deformation of the Al-O-Si } \\
\text { bond and deformation of } \\
\text { the } \mathrm{Si}-\mathrm{O}-\mathrm{Si} \text { bond or elongation } \\
\text { of the Fe-O bond. }\end{array}$ \\
\hline $602.4 ; 665.9$ & $\begin{array}{l}P G \\
B+8 \% L+8 \% P G\end{array}$ & $\begin{array}{l}\text { Asymmetric deformation } \\
\text { of sulfate }\left(\mathrm{V} 4 \mathrm{SO}_{4}\right) \text {. }\end{array}$ \\
\hline $627.1 ; 620$ & $\begin{array}{l}\text { Bentonite } \\
B+8 \% L \\
B+8 \% L+8 \% P G\end{array}$ & $\begin{array}{l}\mathrm{Al}-\mathrm{O} \text { and } \mathrm{Si}-\mathrm{O} \text { out-of- } \\
\text { plane vibrations. }\end{array}$ \\
\hline 701.2 & $\begin{array}{l}\text { Bentonite } \\
B+8 \% L \\
B+8 \% L+8 \% P G\end{array}$ & $\mathrm{Si}-\mathrm{O}-\mathrm{Si}$ \\
\hline $803.6 ; 1040.1$ & $\begin{array}{l}\text { Bentonite } \\
B+8 \% L \\
B+8 \% L+8 \% P G\end{array}$ & $\begin{array}{l}\text { Elongation vibration of } \\
\text { the Si-O bond. }\end{array}$ \\
\hline $874.2 ; 1431.8$ & $\begin{array}{l}B+8 \% L \\
B+8 \% L+8 \% P G\end{array}$ & $\begin{array}{l}\text { C-O stretching vibration } \\
\text { of calcite. }\end{array}$ \\
\hline 916.5 & $\begin{array}{l}\text { Bentonite } \\
B+8 \% L \\
B+8 \% L+8 \% P G\end{array}$ & $\begin{array}{l}\text { Deformation of the } \\
\text { Al-Al-OH bond. }\end{array}$ \\
\hline 1156.5 & $\begin{array}{l}B+8 \% L \\
B+8 \% L+8 \% P G\end{array}$ & $\begin{array}{l}\text { Asymmetric elongation } \\
\text { of sulfate }\left(\mathrm{V}_{3} \mathrm{SO}_{4}\right) \text {. }\end{array}$ \\
\hline $1622.4 ; 1689.4$ & PG & $\begin{array}{l}\text { Water molecule deformation } \\
\text { vibrations }\left(\mathrm{V}_{2} \mathrm{H}_{2} \mathrm{O}\right) \text {. }\end{array}$ \\
\hline $1650.5 ; 1644$ & $\begin{array}{l}\text { Bentonite } \\
B+8 \% L \\
B+8 \% L+8 \% P G\end{array}$ & $\begin{array}{l}\text { Bonds assigned to hydroxyl } \\
\text { stretching and } \mathrm{H}-\mathrm{O}-\mathrm{H} \\
\text { bending vibrations of } \\
\text { interlayer water molecules } \\
\text { on montmorillonite. }\end{array}$ \\
\hline $3411.7 ; 3556.4$ & $P G$ & $\begin{array}{l}\text { Symmetrical and asymmetrical } \\
\text { elongation of } \mathrm{H}_{2} \mathrm{O}\left(\mathrm{v}_{1} \mathrm{H}_{2} \mathrm{O}\right) \text {. }\end{array}$ \\
\hline 3673.6; 3708.2 & $\begin{array}{l}\text { Bentonite } \\
B+8 \% L \\
B+8 \% L+8 \% P G\end{array}$ & Adsorbed water molecules. \\
\hline
\end{tabular}

$B$ Bentonite, $L$ Lime

well as on the abundance of $\mathrm{Ca}^{2+}$ and $\mathrm{OH}^{-}$. Once all the ions $\mathrm{Ca}^{2+}$ and $\mathrm{OH}^{-}$are consumed, the $\mathrm{pH}$ drops and the pozzolanic reactions cease [39]. In a solution containing silicates, when sufficient calcium ions are introduced $\left(\left[\mathrm{Ca}^{2+}\right]>1.7 \mathrm{mM}\right)$, the calcium hydroxide reacts with silica in bentonite based mixture to form silica gel [40]. The $\mathrm{pH}$ reduction is due to lime consumption for pozzolanic reaction as cation exchange does not affect the $\mathrm{OH}^{-}$concentration. The slow decrease in $\mathrm{pH}$ is due to the slow activity of the reaction at room temperature, the decrease in calcium amount and the extension of curing time $[41,42]$.

\section{Bentonite-lime-phosphogypsum mixture $(p H=8.8)$}

The gypsum originating from PG fills up the void spaces left out after the rapid reaction of bentonite with lime, resulting in base exchange aggregation and flocculation
[43]. The presence of gypsum in lime-stabilized clay provides further $\mathrm{Ca}^{2+}$ cations in addition to those provided by lime and $\left[\mathrm{SO}_{4}\right]^{2-}$ anions. The supply of $\mathrm{Ca}^{2+}$ cations increases the overall number of cations attracted to the surface of montmorillonite particles [38]. Alternatively, montmorillonite dissolution rate strongly depends on the $\mathrm{pH}$ of the solution, with a minimum value between 8 and 8.5 [44]. In addition, the presence of organic matter in PG, such as humic and fulvic acids will further increase cation exchange capacity of bentonite [45]. This results in increasing $\mathrm{Ca}^{2+}$ amount to satisfy the cation exchange capacity of the mixture and thereby reduces the amount of $\mathrm{Ca}^{2+}$ available for CSH formation [46].

The occurrence of $\mathrm{F}^{-}$together with $\mathrm{PO}_{4}{ }^{3-}$ containing in PG causes the formation of inactive and protective coatings of $\mathrm{Ca}_{3}\left(\mathrm{PO}_{4}\right)_{2}$ and $\mathrm{CaF}_{2}$ compounds on the surface of cement grains in the mixture. This should temporarily stop the hydration of cement [47].

The pozzolanic reactions are also modified by sulphates occurrence in the parent aggregate material [48]. The PG has a residual acidity giving a $\mathrm{pH}=2.7$. According to Falaras et al. [49], the activation with concentrated acids increases the acidity of the surface, leading to the destruction of the crystal lattice. This should change the number of active sites (i.e., release of oxides of aluminum and silicon), and therefore the pozzolanic reactions are accelerated by the presence of PG $[24,49]$.

\section{The influence of $\mathrm{Ca}, \mathrm{Al}, \mathrm{Na}$ and $\mathrm{Si}$}

The lime addition increases the $\mathrm{Ca} / \mathrm{Si}$ ratio of bentonite. Moreover, the $\mathrm{Na} / \mathrm{Si}$ ratio also increased, leading to the migration of $\mathrm{Na}^{+}$ions to the surface resulting from the substitution by $\mathrm{Ca}^{2+}$ ions. Cementation occurs as a result of $\mathrm{CSH}$ gel development on the grain surface of montmorillonite, thereby increasing the content of $\mathrm{Ca}^{2+}$. The $\mathrm{Si} / \mathrm{Al}$ ratio of lime-bentonite decreases and allows the inception of aluminate formation of $\mathrm{CAH}$ gel and strätlingite. The lower content of calcium hydroxide prevents or postpones the formation of ettringite. The latter is inhibited at an early stage and instead strätlingite $\left(\mathrm{Ca}_{2} \mathrm{Al}_{2} \mathrm{SiO}_{2}(\mathrm{OH})_{10} \cdot 3 \mathrm{H}_{2} \mathrm{O}\right)$ forms with soluble silicates [50].

The PG addition decreases the $\mathrm{Ca} / \mathrm{Si}$ and $\mathrm{Si} / \mathrm{Al}$ ratio. $\mathrm{Ca}^{2+}$ and $\mathrm{Al}^{3+}$ are consumed by the strätlingite formation (gehlenite hydrate) and CSH gel [51]. Winnefeld and Lothenbach [52] concluded that strätlingite cannot coexist with gypsum or portlandite. Portlandite appears as a stable phase and replaces strätlingite. In our case, the occurrence of phosphates, fluorides and sulfates present in PG stabilized strätlingite. Portlandite $(\mathrm{d}(\mathrm{hkl})=$ $2.627 \AA$ ) was not detected by XRD nor SEM in the bentonite-lime-PG mixtures. 


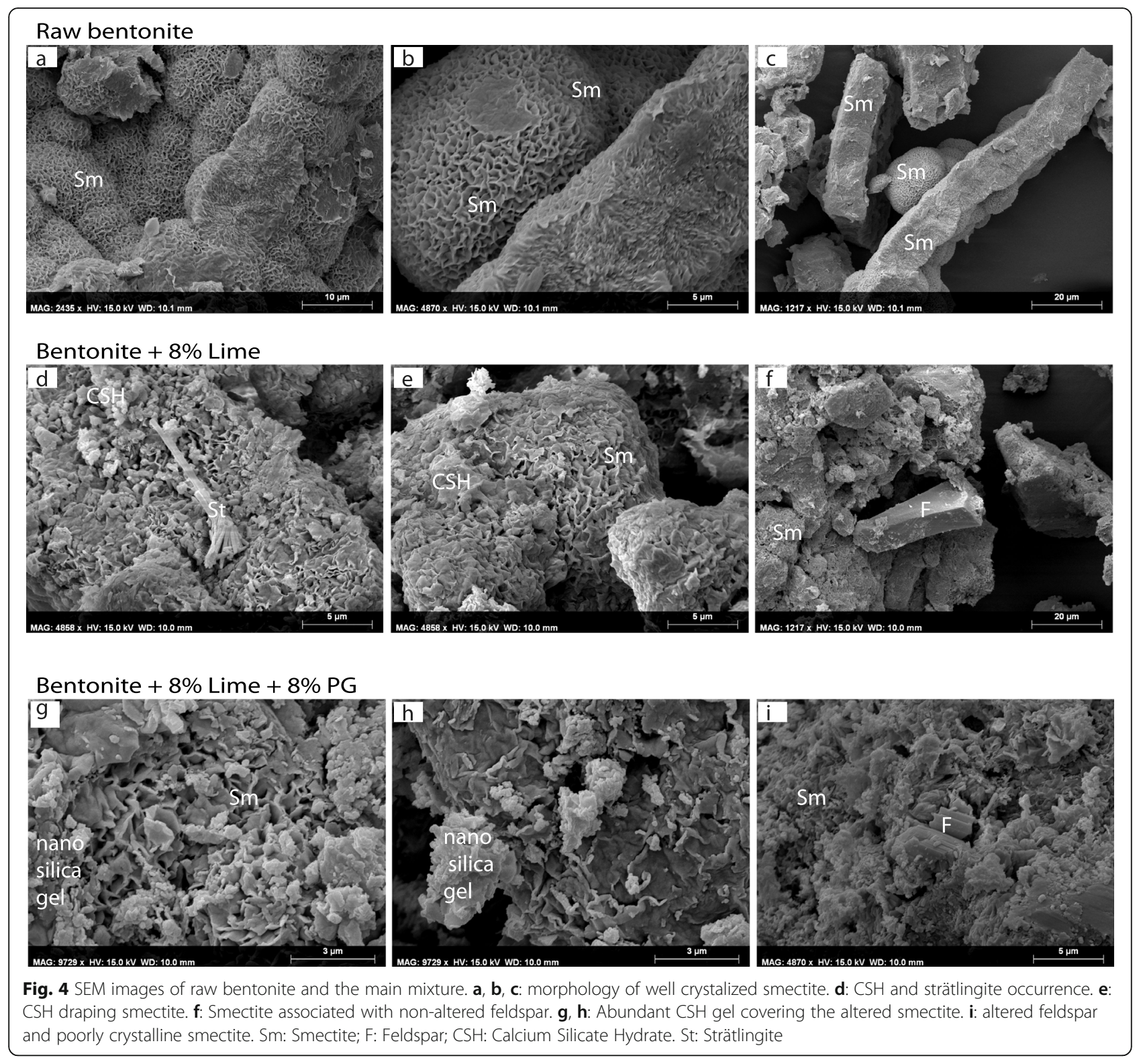

\section{Conclusions}

The effect of raw bentonite (Ca-Na montmorillonite), PG waste, and lime on the properties of cementitious materials has been investigated through various tests. Mechanical strength was improved for cement based on

Table $4 \mathrm{pH}$ values and the $\mathrm{Si} / \mathrm{Al}, \mathrm{Ca} / \mathrm{Si}, \mathrm{Na} / \mathrm{Si}$ ratios of raw materials and the main mixtures

\begin{tabular}{lllll}
\hline Samples & $\mathrm{pH}$ & $\mathrm{Si} / \mathrm{Al}$ & $\mathrm{Ca} / \mathrm{Si}$ & $\mathrm{Na} / \mathrm{Si}$ \\
\hline Bentonite & 8.2 & 2.09 & 0.02 & 0.03 \\
PG & 2.7 & 4.55 & 63.0 & - \\
Lime & 12.7 & - & - & - \\
Bentonite + 8\% Lime & 9.6 & 1.91 & 0.13 & 0.12 \\
Bentonite + 8\% Lime + 8\% PG & 8.8 & 1.90 & 0.05 & 0.17 \\
\hline
\end{tabular}

$8 \%$ of lime mixed with bentonite. Cementation implies disappearance of portlandite and the formation of $\mathrm{CSH}$ nanocrystalline phases. Further increases in mechanical strength occurred when $8 \%$ of PG waste was added to $8 \%$ of lime and bentonite. This improvement is the consequence of strätlingite neoformation through pozzoloanic reaction. This reaction occurs simultaneous with the hydrolysis of calcite and $\mathrm{k}$-feldspar containing in lime and bentonite, respectively.

The observed geoplymerisation is mainly controlled by $\mathrm{pH}$ and the amounts of $\mathrm{Ca}, \mathrm{Al}, \mathrm{Na}$ and $\mathrm{Si}$ of the aggregate added to bentonite. The formation of new hydrated crystalline phases and gel occurs in alkaline condition with low $\mathrm{Na}$ and $\mathrm{Ca}$ amount $(\mathrm{Ca} / \mathrm{Si}$ and $\mathrm{Na} / \mathrm{Si}<0.1$. 


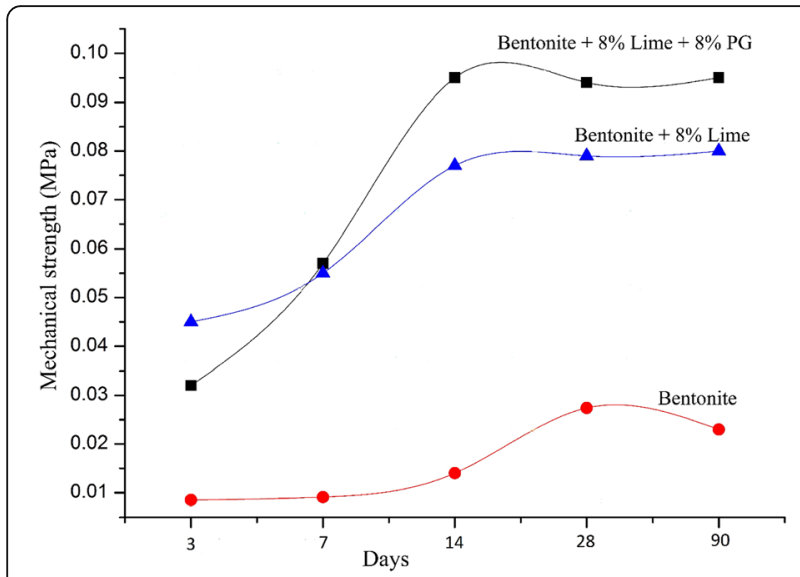

Fig. 5 Compressive strength curves of raw bentonite and the mixtures

The lime addition increased the $\mathrm{Ca} / \mathrm{Si}$ and $\mathrm{Na} / \mathrm{Si}$ ratios, causing cementation due to the CSH gel development on the grain surface of montmorillonite. While, PG decreases the Si/Al ratio and leads to the formation of CSH gel and strätlingite.

\section{Acknowledgments}

This research was supported by 2 Erasmus grants from the University of Liege to Safae OUMNIH and Nadia BEKKOUCH. The author express gratitude to the Office Chérifien des Phosphates (OCP) for providing phosphorgypsum samples.

\section{Authors' contributions}

Author's contributions are described as the following: Acquisition of data: SO and NB. Analysis and interpretation of data: SO, NB, EKG, MEO, and KE. Drafting of manuscript: SO, MEO and EKG. Critical revision: NF, MEO, EKG and KE. All authors read and approved the final manuscript.

\section{Funding}

'Not applicable' for that section.

\section{Availability of data and materials}

The authors are able to make data and associated protocols promptly available to readers without undue qualifications.

\section{Competing interests}

The authors declare that they have no competing interests.

\section{Author details}

'Department of Geology, University of Liege, B-4000 Liege, Belgium. 2Department of Chemistry, University Mohammed First, 60000 Oujda, Morocco. ${ }^{3}$ Department of Geology, University Mohammed First, 60000 Oujda, Morocco.

Received: 9 July 2019 Accepted: 15 November 2019 Published online: 16 December 2019

\section{References}

1. FE. Best available techniques for pollution prevention and control in the European fertilizer industry. Production of phosphoric acid. Brussels: Fertilizers Europe; 2000.

2. Rashad AM. Phosphogypsum as a construction material. J Clean Prod. 2017; 166:732-43.

3. Papastefanou C, Stoulos S, loannidou A, Manolopoulou A. The application of phosphogypsum in agriculture and the radiological impact. J Environ Radioactiv. 2006;89:188-98.
4. Degirmenci N, Okucu A, Turabi A. Application of phosphogypsum in soil stabilization. Build Environ. 2007:42:3393-8.

5. Contreras M, Teixeira SR, Santos GTA, Gazquez MJ, Romero M, Bolivar JP. Influence of the addition of phosphogypsum on some properties of ceramic tiles. Constr Build Mater. 2018;175:588-600.

6. Xue SG, Li M, Jiang J, Millar GJ, Li CX, Kong XF. Phosphogypsum stabilization of bauxite residue: conversion of its alkaline characteristics. J Environ Sci-China. 2019;77:1-10.

7. Van VTA, Nguyen VB. Using refined phosphogypsum to replace natural gypsum in Portland cement production in Vietnam. Int I Sustain Energy Environ Res. 2019:8:62-9.

8. Oumnih S, Gharibi EK, Yousfi EB, Bekkouch N, El Hammouti K. Posphogypsum waste valorization by acid attack with the presence of metallic iron. J Mater Environ Sci. 2017;8:338-44.

9. Gaudry A, Zeroual S, Gaie-Levrel F, Moskura M, Boujrhal FZ, El Moursli RC, et al. Heavy metals pollution of the Atlantic marine environment by the Moroccan phosphate industry, as observed through their bioaccumulation in Ulva lactuca. Water Air Soil Poll. 2007;178:267-85.

10. Papaslioti EM, Perez-Lopez R, Parviainen A, Sarmiento AM, Nieto JM, Marchesi $C$, et al. Effects of seawater mixing on the mobility of trace elements in acid phosphogypsum leachates. Mar Pollut Bull. 2018;127:695703.

11. Nanni A, Chang WF. Phosphogypsum-based roller compacted concrete. Concr Int. 1989;11:48-53.

12. Huang $Y$, Lin ZS. Investigation on phosphogypsum-steel slag-granulated blast-furnace slag-limestone cement. Constr Build Mater. 2010;24:1296-301.

13. Chen QS, Zhang QL, Qi CC, Fourie A, Xiao CC. Recycling phosphogypsum and construction demolition waste for cemented paste backfill and its environmental impact. J Clean Prod. 2018;186:418-29.

14. Chen T, Chen DY, Mi Y, Wang SZ, Wang N. Experimental research on decorative mortar prepared by calcined gypsum from phosphogypsum. China Concr Cem Pro. 2018:4:77-80 [in Chinese].

15. Nawaz A, Julnipitawong $P$, Krammart $P$, Tangtermsirikul S. Effect and limitation of free lime content in cement-fly ash mixtures. Constr Build Mater. 2016;102:515-30.

16. Van Damme H, Houben H. Earth concrete. Stabilization revisited. Cement Concrete Res. 2018;114:90-102.

17. Hashemi MA, Massart TJ, Salager S, Herrier G, Francois B. Pore scale characterization of lime-treated sand-bentonite mixtures. Appl Clay Sci. 2015;111:50-60.

18. James J, Pandian PK. Industrial wastes as auxiliary additives to cement/lime stabilization of soils. Adv Civ Eng. 2016;2016:1267391.

19. Wyszkowska J, Wyszkowski M. Role of compost, bentonite and lime in recovering the biochemical equilibrium of diesel oil contaminated soil. Plant Soil Environ. 2006;52:505-14.

20. Ruiz MC, Irabien A. Environmental behavior of cement-based stabilized foundry sludge products incorporating additives. J Hazard Mater. 2004;109: 45-52.

21. Maubec N, Deneele D, Ouvrard G. Influence of the clay type on the strength evolution of lime treated material. Appl Clay Sci. 2017;137:107-14.

22. Rajasekaran G. Sulphate attack and ettringite formation in the lime and cement stabilized marine clays. Ocean Eng. 2005;32:1133-59.

23. Yilmaz I, Civelekoglu B. Gypsum: an additive for stabilization of swelling clay soils. Appl Clay Sci. 2009:44:166-72.

24. Shen WG, Zhou MK, Zhao QL. Study on lime-fly ash-phosphogypsum binder. Constr Build Mater. 2007;21:1480-5.

25. Kumar S, Dutta RK, Mohanty B. Engineering properties of bentonite stabilized with lime and phosphogypsum. Slovak J Civ Eng. 2014;22:35-44.

26. Aalaoul M, Azdimousa A, El Hammouti K. Bentonite's reserves geometry of Trebia deposit in Nador region (north eastern Morocco); contributions of geophysical surveys and core drilling campaign. J Mater Environ Sci. 2015;6: 3564-73.

27. Ddani M, Meunier A, Zahraoui M, Beaufort D, El Wartiti M, Fontaine C, et al. Clay mineralogy and chemical composition of bentonites from the Gourougou volcanic massif (Northeast Morocco). Clay Clay Miner. 2005;53: 250-67.

28. Rutherford PM, Dudas MJ, Arocena JM. Heterogeneous distribution of radionuclides, barium and strontium in phosphogypsum by-product. Sc Total Environ. 1996;180:201-9.

29. Perez-Lopez R, Alvarez-Valero AM, Nieto JM. Changes in mobility of toxic elements during the production of phosphoric acid in the fertilizer industry 
of Huelva (SW Spain) and environmental impact of phosphogypsum wastes. J Hazard Mater. 2007;148:745-50.

30. Bondar D, Lynsdale CJ, Milestone NB, Hassani N, Ramezanianpour AA. Effect of type, form, and dosage of activators on strength of alkali-activated natural pozzolans. Cement Concrete Comp. 2011;33:251-60.

31. Firdous R, Stephan D, Djobo JNY. Natural pozzolan based geopolymers: a review on mechanical, microstructural and durability characteristics. Constr Build Mater. 2018;190:1251-63.

32. Kouamo HT, Elimbi A, Mbey JA, Sabouang CJN, Njopwouo D. The effect of adding alumina-oxide to metakaolin and volcanic ash on geopolymer products: a comparative study. Constr Build Mater. 2012;35:960-9.

33. Taylor HF. Cement chemistry. 2nd ed. London: Thomas Telford; 1997.

34. Puppala AJ, Intharasombat N, Vempati RK. Experimental studies on ettringite-induced heaving in soils. J Geotech Geoenviron. 2005;131:325-37.

35. Mitchell JK, Soga K. Fundamentals of soil behavior. 3rd ed. Hoboken: Wiley; 2005.

36. Palou M, Majling J, Doval M, Kozankova J, Mojumdar SC. Formation and stability of crystallohydrates in the non-equilibrium system during hydration of SAB cements. Ceram-Silikaty. 2005;49:230-6.

37. Khattab SAA, Al-Mukhtar M, Fleureau JM. Long-term stability characteristics of a lime-treated plastic soil. J Mater Civil Eng. 2007;19:358-66.

38. Tilak BV, Dutta RK, Mohanty B. Strength characteristics of bentonite-limegypsum mix reinforced with coir fibres. Eur J Environ Civ En. 2015;19:1108-35.

39. Consoli NC, Lopes LD, Prietto PDM, Festugato L, Cruz RC. Variables controlling stiffness and strength of lime-stabilized soils. J Geotech Geoenviron. 2011;137:628-32.

40. Memon SA, Arsalan R, Khan S, Lo TY. Utilization of Pakistani bentonite as partial replacement of cement in concrete. Constr Build Mater. 2012;30:237-42.

41. Chen L, Lin DF. Stabilization treatment of soft subgrade soil by sewage sludge ash and cement. J Hazard Mater. 2009;162:321-7.

42. Al-Mukhtar M, Lasledj A, Alcover JF. Behaviour and mineralogy changes in lime-treated expansive soil at $20^{\circ} \mathrm{C}$. Appl Clay Sci. 2010;50:191-8.

43. Tilak BV, Dutta RK, Mohanty B. Effect of coir fibres on the compaction and unconfined compressive strength of bentonite-lime-gypsum mixture. Slovak J Civ Eng. 2015;23:1-8.

44. Huertas FJ, Caballero E, de Cisneros CJ, Huertas F, Linares J. Kinetics of montmorillonite dissolution in granitic solutions. Appl Geochem. 2001;16: 397-407.

45. Tan KH. Humic matter in soil and the environment: principles and controversies. 2nd ed. Boca Raton: CRC Press; 2014.

46. Harvey OR, Harris JP, Herbert BE, Stiffler EA, Haney SP. Natural organic matter and the formation of calcium-silicate-hydrates in lime-stabilized smectites: a thermal analysis study. Thermochim Acta. 2010;505:106-13.

47. Singh M. Treating waste phosphogypsum for cement and plaster manufacture. Cement Concrete Res. 2002;32:1033-8.

48. Kinuthia JM, Wild S, Jones Gl. Effects of monovalent and divalent metal sulphates on consistency and compaction of lime-stabilised kaolinite. Appl Clay Sci. 1999;14:27-45

49. Falaras P, Kovanis I, Lezou F, Seiragakis G. Cottonseed oil bleaching by acidactivated montmorillonite. Clay Miner. 1999:34:221-32.

50. Ronne M, Hammer TA. Delayed ettringite formation (DEF) in structural lightweight aggregate concrete: effect of curing temperature, moisture, and silica fume content. Cement Concrete Aggr. 1999;21:202-11.

51. Damidot D, Glasser FP. Investigation of the $\mathrm{CaO}-\mathrm{Al}_{2} \mathrm{O}_{3}-\mathrm{SiO}_{2}-\mathrm{H}_{2} \mathrm{O}$ system at $25^{\circ} \mathrm{C}$ by thermodynamic calculations. Cement Concrete Res. 1995;25:22-8.

52. Winnefeld $\mathrm{F}$, Lothenbach $\mathrm{B}$. Phase equilibria in the system $\mathrm{Ca}_{4} \mathrm{Al}_{6} \mathrm{O}_{12} \mathrm{SO}_{4}-$ $\mathrm{Ca}_{2} \mathrm{SiO}_{4}-\mathrm{CaSO}_{4}-\mathrm{H}_{2} \mathrm{O}$ referring to the hydration of calcium sulfoaluminate cements. RlLEM Tech Lett. 2016;1:10-6.

\section{Publisher's Note}

Springer Nature remains neutral with regard to jurisdictional claims in published maps and institutional affiliations.

\section{Ready to submit your research? Choose BMC and benefit from:}

- fast, convenient online submission

- thorough peer review by experienced researchers in your field

- rapid publication on acceptance

- support for research data, including large and complex data types

- gold Open Access which fosters wider collaboration and increased citations

- maximum visibility for your research: over $100 \mathrm{M}$ website views per year

At BMC, research is always in progress.

Learn more biomedcentral.com/submissions 